medRxiv preprint doi: https://doi.org/10.1101/2020.05.26.20113324; this version posted December 1, 2020. The copyright holder for this preprint (which was not certified by peer review) is the author/funder, who has granted medRxiv a license to display the preprint in

All rights reserved. No reuse allowed without permission.

\title{
Wading through Molasses: A qualitative examination of the experiences, perceptions, attitudes, and knowledge of Australian medical practitioners regarding medical billing
}

Margaret Faux ${ }^{1,2}$, Jon Adams ${ }^{1}$, Simran Dahiya $^{3}$, Jon Wardle $^{1 \& 4}$

${ }^{1}$ School of Public Health, Faculty of Health, University of Technology, Sydney, Australia

${ }^{2}$ Solicitor of the Supreme Court of NSW and the High Court of Australia

${ }^{3}$ Faculty of Medicine, University of New South Wales, Australia

${ }^{4}$ Southern Cross University, Australia

Corresponding author

margaret.a.faux@student.uts.edu.au

\section{Contributorship Statement}

Margaret Faux - This paper reports the results of the final phase of a three phase PhD project

by Ms Faux. As such Ms Faux wrote the first draft of the paper in its entirety and has

finalised all subsequent drafts incorporating feedback and suggestions from the other authors.

She is responsible for the concept and design of the study, conducted all data collection and analysed and interpreted the results.

Professor Jon Adams - second author Professor Adams is the co-supervisor of Ms Faux's

Doctorate. Professor Adams has made substantial contributions to later drafts of this paper via review and re-drafting of important intellectual content.

Simran Dahiya - third author Simran Dahiya listened to the audio recordings of all interviews, reviewed the transcripts to ensure accuracy and was also involved in the data NOTE: This preprint reports new research that has not been certified by peer review and should not be used to guide clinical practice. 
medRxiv preprint doi: https://doi.org/10.1101/2020.05.26.20113324; this version posted December 1 , 2020. The copyright holder for this preprint (which was not certified by peer review) is the author/funder, who has granted medRxiv a license to display the preprint in All rights reserved. No reuse allowed without permission.

analysis and interpretation. She made important contributions to content in the findings and discussion sections of the paper as a result of her close association with the data.

Professor Jon Wardle - last author Professor Wardle is the principal supervisor for Ms Faux's Doctorate. Professor Wardle has made substantial contributions to this paper at every stage, including having involvement in the proposed concept and design of the study, through to making substantial contributions to the paper via review, critical analysis, feedback and redrafting sections of the paper to refine important intellectual content. 
medRxiv preprint doi: https://doi.org/10.1101/2020.05.26.20113324; this version posted December 1, 2020. The copyright holder for this preprint (which was not certified by peer review) is the author/funder, who has granted medRxiv a license to display the preprint in

All rights reserved. No reuse allowed without permission.

\title{
Wading through Molasses: A qualitative examination of the experiences, perceptions, attitudes, and knowledge of Australian medical practitioners regarding medical billing
}

\begin{abstract}
Background

Medical billing errors and fraud have been described as one of the last "great unreduced healthcare costs," with some commentators suggesting measurable average losses from this phenomenon are $7 \%$ of total health expenditure. In Australia, it has been estimated that leakage from Medicare caused by non-compliant medical billing may be $10-15 \%$ of the scheme's total cost. Despite a growing body of international research, mostly from the U.S, suggesting that rather than deliberately abusing the health financing systems they operate within, medical practitioners may be struggling to understand complex and highly interpretive medical billing rules, there is a lack of research in this area in Australia. The aim of this study was to address this research gap by examining the experiences of medical practitioners through the first qualitative study undertaken in Australia, which may have relevance in multiple jurisdictions.
\end{abstract}

\section{Method}

This study interviewed 27 specialist and general medical practitioners who claim Medicare reimbursements in their daily practice. Interviews were recorded, transcribed, and analysed using thematic analysis.

\section{Results}

The qualitative data revealed five themes including inadequate induction, poor legal literacy, absence of reliable advice and support, fear and deference, and unmet opportunities for improvement. 
medRxiv preprint doi: https://doi.org/10.1101/2020.05.26.20113324; this version posted December 1 , 2020. The copyright holder for this preprint (which was not certified by peer review) is the author/funder, who has granted medRxiv a license to display the preprint in

All rights reserved. No reuse allowed without permission.

\section{Conclusion}

The qualitative data presented in this study suggest Australian medical practitioners are illequipped to manage their Medicare compliance obligations, have low levels of legal literacy and desire education, clarity and certainty around complex billing standards and rules. Noncompliant medical billing under Australia's Medicare scheme is a nuanced phenomenon that may be far more complex than previously thought and learnings from this study may offer important insights for other countries seeking solutions to the phenomenon of health system leakage. Strategies to address the barriers and deficiencies identified by participants in this study will require a multi-pronged approach. The data suggest that the current punitive system of ensuring compliance by Australian medical practitioners is not fit for purpose.

\section{Introduction}

Medical billing errors and fraud have been described as one of the last "great unreduced healthcare costs," with some commentators suggesting measurable average losses from this phenomenon are $7 \%$ of total health expenditure ${ }^{1}$. It is therefore central to the long-term economic viability of any health system that medical practitioners have clarity and certainty around relevant billing standards and rules. However, a growing body of international research, mostly from the U.S, suggests medical practitioners are ill equipped to understand the complexities of the health systems in which they work.

Like the reported experiences of their U.S colleagues, evidence suggest Australian medical practitioners may be experiencing difficulty navigating complex medical billing rules. ${ }^{2}$ It has been suggested that the rate of non-compliant billing under Australia's Medicare caused by deliberate abuses by medical practitioners is between $10-15 \% .^{3}$ However, how much non- 
medRxiv preprint doi: https://doi.org/10.1101/2020.05.26.20113324; this version posted December 1 , 2020. The copyright holder for this preprint (which was not certified by peer review) is the author/funder, who has granted medRxiv a license to display the preprint in

All rights reserved. No reuse allowed without permission.

compliant billing is deliberate is uncertain, as it rests in a spectrum with criminal fraud at one end and unintentional errors at the other and currently the precise quantum of each is unknown. ${ }^{4}$ This is largely because the problem is not what can be seen, but what cannot. Lax regulation, government maladministration, system complexity and the fact that medical practitioners are never taught how to use the system correctly at any point in their careers have all been cited as factors contributing to this problem. ${ }^{4}$ Increasing complexity has occurred in tangent with increased penalties for non-compliance ${ }^{5}$ and pressure on medical practitioners to bill correctly has reached the point where some authors have suggested that compliance with Medicare billing rules has become a contributing factor to medical practitioner burnout and suicide. ${ }^{6}$ However, one area of activity that has been overlooked is improving user knowledge of the medical billing system.

Multiple recent U.S studies on the topic of medical billing literacy ${ }^{7}$ have consistently reported demonstrably low literacy which may be improved by targeted educational initiatives, including by medical billing and coding education being a mandatory inclusion in the medical curriculum. However, an apparent inertia to act persists. In Australia, discussion around this topic is less mature, with very little similar research having been undertaken.

The aim of this study was therefore to address this research gap by examining the experiences of Australian medical practitioners in grass roots practice as they interact with Medicare and claim reimbursements under Australia's unique Medicare Benefits Schedule (MBS) codes. ${ }^{8}$ This study will also explore medical practitioner knowledge of medical billing requirements, attitudes and perceptions to Medicare, and seek to identify any barriers to compliance as well as exploring possible solutions to deficiencies in current arrangements. 
medRxiv preprint doi: https://doi.org/10.1101/2020.05.26.20113324; this version posted December 1, 2020. The copyright holder for this preprint (which was not certified by peer review) is the author/funder, who has granted medRxiv a license to display the preprint in

All rights reserved. No reuse allowed without permission.

\section{Methods}

Between July 2016 and May 2019, semi structured interviews were conducted with specialist and general medical practitioners both of whom are required to claim Medicare reimbursements in their daily work. The study was geographically restricted to the State of New South Wales, was approved by the relevant Human Research Ethics Committee and consent was obtained from all participants. Participant information has been de-identified to preserve anonymity.

\section{Participants}

Twenty-seven interviews were conducted, twelve with General Practitioners (GP) and fifteen with Salaried Medical Officers (SMO), the latter of whom are specialists working in Australian public hospitals. Participants were recruited through advertising with their professional associations, direct approaches and "snowballing". Participant demographics included 11 females and 16 males and a mix of overseas and Australian trained medical practitioners, who worked in both regional and city locations. The full spectrum of career stages was represented, including early career stage medical practitioners (defined as 0-7 years postgraduation) through to those who had practiced medicine for over 30 years. The SMO cohort included a variety of procedural and non-procedural specialists.

\section{Data collection}

Medical practitioners who responded to initial contact were sent an information sheet, consent form and a short overview of the research via email, and those who participated signed the consent form prior to the interview. 
medRxiv preprint doi: https://doi.org/10.1101/2020.05.26.20113324; this version posted December 1 , 2020. The copyright holder for this preprint (which was not certified by peer review) is the author/funder, who has granted medRxiv a license to display the preprint in

All rights reserved. No reuse allowed without permission.

Although every effort was made to identify participants who were not known to the principal researcher (first author), being someone who has worked in the medical billing industry for over 30 years it was likely that some participants would have a coexisting relationship. One GP and one SMO were personally known to the principle researcher, and another GP and SMO were professionally known. In addition, three SMOs were professional acquaintances. While this was unavoidable, it is not uncommon in qualitative research projects (for example a nurse questioning other nurses in their organisation as part of a project).

To ensure personal relationships (none of which were close) did not cloud data collection, the principal researcher continued to have regular discussions with other members of the research team adopting reflective practice to eliminate bias and ensure research integrity. Further, the third author listened to the audio recordings of all interviews and provided important insights when reviewing the draft paper to ensure data were accurately reflected and reported, with additional input from other authors as required.

To address possible conscious or unconscious bias, triangulation was used where an experienced qualitative researcher separately analysed and interpreted the data and any differences in researcher perspectives were cross checked to arrive at an overall interpretation. By implementing these accepted methods rigour, trustworthiness, authenticity and credibility were addressed. ${ }^{9}$

As this study forms part of the doctoral thesis of the principal researcher, it was incumbent upon her to personally conduct as much of the work as possible. However, this project was at all times closely supervised by the last author, who is a senior researcher experienced in 
medRxiv preprint doi: https://doi.org/10.1101/2020.05.26.20113324; this version posted December 1 , 2020. The copyright holder for this preprint (which was not certified by peer review) is the author/funder, who has granted medRxiv a license to display the preprint in All rights reserved. No reuse allowed without permission.

qualitative data collection. The principal researcher had ongoing discussions with the last author throughout the data collection phase and during the analysis and coding of the data.

Further, to ensure research integrity the last author directly sat in and supervised the first two interviews (including with the GP who had a personal relationship). Following approval of the first two interviews, the principal researcher continued and personally conducted all 27 interviews. Most of the interviews were conducted in person $(n=23)$ at a place and time convenient to the participants. Due to geographical barriers, some of the regional GP interviews were conducted by phone $(n=4)$.

Two listeners and two independent coders analysed the data in line with qualitative research norms. The third author listened to the audio recordings of all interviews and edited final transcripts to ensure accuracy. After discussion with the last author regarding emergent themes, the first and third authors worked together to code the data, with the other authors reviewing in areas that required resolution to disagreements.

The interviews were semi-structured, with a question sheet used to loosely guide questioning. Participants were encouraged to speak freely and openly and were given unlimited time to enable full exploration of the topic. The interviews continued until theme saturation had been reached, the average interview length was one hour, and all participants consented to the interviews being recorded. The interviews were subsequently transcribed. 
medRxiv preprint doi: https://doi.org/10.1101/2020.05.26.20113324; this version posted December 1 , 2020. The copyright holder for this preprint (which was not certified by peer review) is the author/funder, who has granted medRxiv a license to display the preprint in

All rights reserved. No reuse allowed without permission.

\section{Data analysis}

The process of data analysis included the five documented steps using the framework approach which is broadly described as familiarisation, identification of framework, charting, mapping and interpretation. ${ }^{10}$

The principal researcher reviewed the manuscripts to familiarise herself with the data including reading and re-reading the transcripts, relistening to the audio files, organising the data for analysis, visually scanning the transcripts and beginning the process of sorting the data to consider its overall meaning. Identification of the framework was then undertaken to draw out key themes and issues from the text around which the data were then organised. The data were then indexed to identify themes and finally, mapping and interpretation was undertaken, whereby associations were clarified, and explanations worked towards.

In order to ensure quality during data analysis, quality assurance measures based upon systematic and self-conscious practice were implemented. ${ }^{9}$ A self-reflective, critical examination of potential bias was also undertaken by the principal researcher, who spent prolonged time in the field engaging with the subject matter.

\section{Findings}

Analysis of the qualitative data revealed five themes related to Medicare and MBS billing, including inadequate induction, poor legal literacy, absence of reliable advice and support, fear and deference, and unmet opportunities for improvement. 
medRxiv preprint doi: https://doi.org/10.1101/2020.05.26.20113324; this version posted December 1, 2020. The copyright holder for this preprint (which was not certified by peer review) is the author/funder, who has granted medRxiv a license to display the preprint in All rights reserved. No reuse allowed without permission.

\section{Inadequate induction into Medicare and MBS billing}

All participants reported their first experience generating a medical bill, or claiming to Medicare, taking place in a knowledge vacuum, where they felt inadequately prepared. As the following quotes suggest, many respondents reported little - if any - training, and if training did occur it was usually brief, informal and taught by someone who may not necessarily have been qualified to teach it:

“...when I did my GP training we had a block of training prior to our very first day on the job...we basically just learnt you know your 23 and 36 item number ${ }^{11}$... there would have been question and answer time, but we hadn't practised yet so we wouldn't really have known what questions to ask.” (GP1)

“...in that induction program there was a guide to claiming, a very brief guide. I think my experience and a lot of other GP trainee's experience was that we had no idea, we were out there, kind of at the coal face, I had zero idea of what we were doing and...it was like walking through molasses, it was very hard to negotiate...It is so hard to understand, ridiculous..."'(GP4)

" [I was] totally naïve, I just believed what he said, thinking he is my senior guy and that was it, so I had no idea that there are legal implications, I had no idea." (GP7)

While most GPs reported a brief induction process, SMOs reported having no induction at all, as explained by the following SMOs:

"Um trial and error, there was no formal introduction, no formal training as you go through... there was no mention of billing...so you navigate it by the skin of your teeth." (SMO11) 
medRxiv preprint doi: https://doi.org/10.1101/2020.05.26.20113324; this version posted December 1, 2020. The copyright holder for this preprint (which was not certified by peer review) is the author/funder, who has granted medRxiv a license to display the preprint in All rights reserved. No reuse allowed without permission.

"I had no idea how Medicare kind of worked ...no one taught me how to bill...I had no idea what it meant to Medicare bill, what gaps were, what scheduled fee was, all the different rates of things were, so it made no sense...there is absolutely no training." (SMO1)

"...when you are a Registrar and when you finish you then realise, oh, there is Medicare. Now what have I been taught about Medicare? Essentially nothing ...you realise you are supposed to bill, but still have no inkling how to do it." (SMO10)

\section{Poor legal literacy of Medicare and MBS billing}

When participants were asked detailed questions about fundamental legal requirements to bill correctly, their levels of literacy were variable and some were confused in important areas, such as when it is permissible to charge a gap and what bulk billing was. ${ }^{12}$

Both of the following quotes were from bulk billing doctors, one of whom did not know the process he was using was bulk billing and the other was unaware he could charge a gap if he wanted to.

“...bulk billing, we do not do bulk billing...really my understanding is it is something that happens in general practice..." (SMO9)

"I think a gap would only be payable if the patient is in hospital where...they have to pay the gap between the doctor's fee and the health fund rebate or gap between the specialist fee and the Medicare rebate, I am not entirely sure of this; I am just guessing from the limited amount of information that I have." (GP8) 
medRxiv preprint doi: https://doi.org/10.1101/2020.05.26.20113324; this version posted December 1 , 2020. The copyright holder for this preprint (which was not certified by peer review) is the author/funder, who has granted medRxiv a license to display the preprint in All rights reserved. No reuse allowed without permission.

When SMOs were asked their understanding of relevant law around bulk billing or charging gaps to patients in public hospital outpatient departments many of their responses highlighted a deep lack of knowledge.

"I think if we as the department decided to charge a gap, we can ...there might be a specific rule, like you cannot charge a gap, but I am not sure, I have never asked questions, I have wondered about it though." (SMO3)

"Can a gap be charged? I actually do not know the answer to that question." (SMO4)

"[billing in the public hospital is] a minefield. My understanding is that for outpatient services in a privatised clinic like this it's quite within our rights to charge a gap, " though when quizzed about the source of that information he said, "Look I do not know the precise details of that; this is just something I have been told." (SMO6)

Confusion about the legalities of this area of public hospital billing extended to GPs, with one GP incorrectly asserting that bulk billing in public hospital outpatient departments is illegal.

"the states are fraudulently thriving on Medicare, in all public hospitals...the practice is frightening...they bulk bill you in the public hospital [outpatient department].” (GP5) 
medRxiv preprint doi: https://doi.org/10.1101/2020.05.26.20113324; this version posted December 1 , 2020. The copyright holder for this preprint (which was not certified by peer review) is the author/funder, who has granted medRxiv a license to display the preprint in All rights reserved. No reuse allowed without permission.

The majority of participants were also unclear about fundamental billing requirements such as what constitutes a valid referral, the rules around billing eligible Veterans, and whether the patient has to sign the bulk bill form.

“Valid referrals, I do not know, I have no understanding of that. I am actually unsure." (GP9)

"...there seems to be at least as far as I am aware (but no one really knows) a practice that anyone who holds the Veterans Affairs Card will not be charged a gap. Whether that is true or not, I do not know." (SMO4)

"I am not really sure, to be honest...I am not sure if it is compulsory, [the bulk bill form] needs to be signed by the patient. I do not really know." (GP9)

When participants were asked how well they thought they complied with current standards some did not know what the standards were or whether such standards existed, and very few participants were aware of the penalties for noncompliance.

"I actually don't know that we would meet the criteria because I don't really know what they are." (SMO15)

"I don't really know... I mean I am sure they could make you pay back the money and there probably is jail time eventually at some point, but to be honest I don't really know what the penalties are." (GP1) 
medRxiv preprint doi: https://doi.org/10.1101/2020.05.26.20113324; this version posted December 1 , 2020. The copyright holder for this preprint (which was not certified by peer review) is the author/funder, who has granted medRxiv a license to display the preprint in All rights reserved. No reuse allowed without permission.

\section{Absence of reliable advice and support}

The majority of participants tended to describe their experiences seeking support and advice from Medicare in negative terms and preferred to direct medical billing questions to practice managers, colleagues, hospital finance departments, professional organisations and in one case, social media.

“...there was something recently that we actually called them up for and then it was some huge kerfuffle and...it kept going round and round....it was about this item number and they just kept reading the same thing we were reading, which was ambiguous. So, it was an utter waste of time." (GP12)

"I always felt like the advice was pretty good but if it got too technical, they were fudging it." (SMO15)

"We get three different answers literally, about the same thing." (GP5)

When asked what gave participants confidence in the medical billing expertise of others, their responses expressed blind faith, difficulties obtaining reliable advice and support and the need to trust someone, as the following quotes demonstrate.

"...the assumption is that...the secretarial staff would have done that before and they will be doing it for other doctors but whether they have had specific training in the rules and regulations around Medicare etc one never really knows... whether they had original training 
medRxiv preprint doi: https://doi.org/10.1101/2020.05.26.20113324; this version posted December 1, 2020. The copyright holder for this preprint (which was not certified by peer review) is the author/funder, who has granted medRxiv a license to display the preprint in All rights reserved. No reuse allowed without permission.

in what was actually required and what was not etc, I suppose it is not something that is very well regulated." (SMO4)

"Looks and appearance, she [the Practice Manager] just appeared to know what she was doing, and I trusted her...I had to." (GP6)

"the bottom line is it [MBS billing] is not clear, and it is not easy to get clarity about some of those issues. " (GP3)

A private Facebook group had become the main source of Medicare billing information for one GP, who felt it was authentic and relying on it would protect her in the event of an audit.

"I do not have a choice but to rely on that because I do not think there is anything else and I realise the problem. If there are other things available, they're not made obvious to us, and I am someone actively seeking out this information. So, if I am looking for it and this is the best that I can find, what would a reasonable group of my peers do differently to what I am doing? Could I rely on that to be investigated? I have to, and I think that that is all I can do because I do not think there are other options..." (GP4)

SMOs reported a preference to seek support from inside the hospitals where they worked, even though some said they didn't know who to ask and others described the information they received as inherently unreliable. No SMO mentioned referencing the National Health Reform Agreement (NHRA), ${ }^{13}$ which is the key agreement between the State and Federal Governments containing the rules for medical billing in public hospitals. 
medRxiv preprint doi: https://doi.org/10.1101/2020.05.26.20113324; this version posted December 1, 2020. The copyright holder for this preprint (which was not certified by peer review) is the author/funder, who has granted medRxiv a license to display the preprint in All rights reserved. No reuse allowed without permission.

"I just feel dumb at these things, I need someone to explain it really in very basic terms to me.

The area of private practice billing [in public hospitals] really baffles me." (SMO3)

"I knew nothing [about billing in public hospitals] so they [the hospital finance department] had to know more than nothing," (SMO7)

All but one participant described education on medical billing throughout their careers in clear, unambiguous terms, summarised by the following typical response.

"[it was] absolutely, totally, totally [inadequate]. Part of the problem, it is very interpretation based, there is no clarity on it. That's really poor and there isn't, to my knowledge, any kind of place that we can go, that in a succinct fashion, in a way that we need it to be, we can have very clear guidance about what we can or we cannot do and I strongly feel that I've had to wing this in terms of pulling stuff together, to make my own knowledge on it.” (GP4)

Most participants understood they were personally responsible for billing, but all had arrangements in place whereby third parties administered billing on their behalf. The advantage of this arrangement was reported as saving time, and the disadvantage was the inherent risk in having diminished control and visibility over the final item numbers submitted to Medicare. SMOs in particular were not confident that the item numbers they put on hospital forms were the same item numbers that were sent to Medicare, because they had very little control over medical billing activities undertaken in their name by the public hospitals where they work.

“...billing under my name in the public hospital in the outpatient department...I cannot see. I could not tell you if anyone did it fraudulently or inappropriately." (SMO7) 
medRxiv preprint doi: https://doi.org/10.1101/2020.05.26.20113324; this version posted December 1, 2020. The copyright holder for this preprint (which was not certified by peer review) is the author/funder, who has granted medRxiv a license to display the preprint in All rights reserved. No reuse allowed without permission.

"As far as the data entry from my perspective, I know that the Medicare billing is correct because I put it in, so the question is two-pronged because one is my part of it and the second part is the part that I do not do...there is a gap there, so I do not know about the second part, because I have not checked." (SMO2)

"...I trust my colleagues but at the end of the day I have no idea." (SMO11)

"I have no control over claiming so I feel very uneasy with the whole process." (SMO10)

Many GPs also expressed concern that they ultimately did not know or have any visibility or control over what was being submitted to Medicare in their names.

“... I actually have no idea that they do what I ask them to do. I have to trust them, which I do of course. But they could be submitting all sorts of weird and wonderful things and I confess that I don't know what they're doing ...you have got to trust someone.” (GP3)

“There's that element of, I'm legally responsible for it and yet someone else is actually pressing the buttons, and maybe there is room for error there that I'm actually liable for, which I haven't even thought about, which is a bit disturbing." (GP2)

All participants described the unreliability of medical billing advice no matter who provided it, but perhaps the most startling example describing the unreliability of government advice was from a SMO who had been audited. This participant described her correct application of a locum billing rule, whereby when acting as a locum for a colleague, the medical practitioner is not permitted to claim an initial attendance item, but must instead claim a subsequent 
medRxiv preprint doi: https://doi.org/10.1101/2020.05.26.20113324; this version posted December 1, 2020. The copyright holder for this preprint (which was not certified by peer review) is the author/funder, who has granted medRxiv a license to display the preprint in All rights reserved. No reuse allowed without permission.

attendance item when a colleague has already reviewed the patient. The participant was subjected to what appears to have been a mishandled audit by Medicare, who did not understand the operation of the rule, which at all relevant times was clearly described in the MBS. As a result of the audit and Medicare's failure to explain to the SMO what she did wrong (which appears to have in fact been nothing), the SMO changed her billing behaviour and is now billing incorrectly and costing Australian taxpayers more.

"I got audited... I then rang Medicare back and I said, "this was the logic for why I claimed 116 [a subsequent consultation]" and I said, "Is this correct or not correct?" And they said, "we are not supposed to advise on the phone." And then I said, "So for me to get some advice, where can I go?" And they said, "you have to look at the MBS schedule." And I said, "I looked at the MBS schedule, I can't find the answers and I have asked my colleagues what they do and half of them do what I do and half of them put 110 [an initial consultation]." So, I never got the right answer. They said they cannot provide any answers. It's pretty poor. I think there are answers that sometimes, you know, you're not quite sure, but don't really know who to ask except for your colleagues and sometimes I feel like the colleagues probably just make it up anyway because they probably don't know. [after the audit] I did change my practice and now I use a 110 when I'm covering somebody else" (SMO10)

\section{Fear and deference}

Most participants spoke positively about Medicare as a health system, describing its purpose as being to provide universal health coverage irrespective of ability to pay, and acknowledged the nexus between their billing and their responsibility for the national health budget. However, some participants commented on the shortcomings and inherent vulnerabilities in an honourbased scheme such as Medicare. 
medRxiv preprint doi: https://doi.org/10.1101/2020.05.26.20113324; this version posted December 1, 2020. The copyright holder for this preprint (which was not certified by peer review) is the author/funder, who has granted medRxiv a license to display the preprint in All rights reserved. No reuse allowed without permission.

"I think we are the gatekeepers of it really, and the responsibility is on us as the doctors who are claiming. I think we need to be really quite careful about how we claim because I think if we are not claiming appropriately, then our health budget is not going to be able to sustain, you know, future healthcare." (GP9)

"Ifeel that I am someone who potentially had a significant impost on national health so I have first practiced the type of medicine that may be different to my peers. I do not order a lot of blood tests. I do not order a lot of scans. I am very interested in, as I said evidence base, I am interested in doing what is needed, I try not to pander to anxiety, it's very difficult, it is much easier to give in and just order a million tests...It is an impost on the national health, so I think there is a responsibility." (SMO7)

“...you have rights to minimise cost to a country and then you have the rights to the patient in front of you, and sometimes that doesn't marry." (GP12)

"Well, the opportunity for cheating is as you can imagine endless. The way you describe your service is entirely up to you...I think most people are not dishonest and most doctors are not dishonest, but still as a tax payer I do not like a system where you can endlessly plunder the public purse with relatively blunt scrutiny." (GP10)

Most participants described billing defensively on occasions due to fear and anxiety of Medicare audits. One participant said she was initially scared of Medicare and recalled thinking when she first started practice, "I will just stick to my $23 s^{11}$ and then I won't do anything wrong." (GP1) 
medRxiv preprint doi: https://doi.org/10.1101/2020.05.26.20113324; this version posted December 1, 2020. The copyright holder for this preprint (which was not certified by peer review) is the author/funder, who has granted medRxiv a license to display the preprint in

All rights reserved. No reuse allowed without permission.

Under-billing was commonly reported, with many participants saying they would always contact Medicare to refund payments if they had made an over-billing mistake but would not correct under-billing errors. One respondent gave a typical response on this issue, "If there is any doubt, I just do not claim it, it is as simple as that. I have a career of more than 20 years and I don't intend to end it prematurely. " (GP5)

Most participants also said they were not comfortable talking about money with their patients, so preferred to have the money handled by someone else and the majority expressed a disinterest in billing, with one respondent providing a typical response, "I think no doctor wants to do their billing themselves, if I have to do billing myself, I probably would not do this." (GP5)

\section{Unmet opportunities for improvement}

A prominent theme was a desire for the current educational deficit to be addressed. Participants had mixed views about the precise place and format of medical billing education with some suggesting a blended approach, whereby content would be provided both at the undergraduate level, and technical details taught later as required.

“...it is difficult to change behaviours of individuals but if you have a robust system, a system that really supports good quality care would be very helpful. Sending some more resources and locating more resources for educating the doctors, by various means be it sending them letters like case examples, emails, having some conferences around, you know, correct Medicare billing etc and educating doctors the implications of incorrect charging particularly over-servicing and fraud, I think that is very important. Doctors just learn from their 
medRxiv preprint doi: https://doi.org/10.1101/2020.05.26.20113324; this version posted December 1, 2020. The copyright holder for this preprint (which was not certified by peer review) is the author/funder, who has granted medRxiv a license to display the preprint in All rights reserved. No reuse allowed without permission.

colleagues and others, you know, we are hearing stories, it is not something they are actively involved in, so there should be an education process and may be even attaching some category points, you know quality, category points that if the doctors understood Medicare and I think that is very important. The system is there but is not enough education about it." (GP8)

"I think if doctors in training have a very good understanding of how hospitals run, how Medicare works, how a private practice works, they will from the very beginning be much more engaged in trying to ensure that the funding is provided in an equitable manner and it is not trying to rort the system or do anything like that but is being aware of how things work...I think it is essential." (SMO4)

"[The educational deficit is a] massive gap...if people are going to be working in the Australian Health System, they need to understand the remuneration and how it occurs in our health system, I think health economics is equally important and there is nothing taught about health economics." (GP7)

"A lot of people would look at medicine and say, well look, people seem to get good salaries and a good lifestyle and that sort of thing... to understand that isn't just going, "so well, doctors seem to be having a good time, but I don't really want to know the mechanism of it." I think understanding the mechanism is really important." (SMO1) 
medRxiv preprint doi: https://doi.org/10.1101/2020.05.26.20113324; this version posted December 1, 2020. The copyright holder for this preprint (which was not certified by peer review) is the author/funder, who has granted medRxiv a license to display the preprint in

All rights reserved. No reuse allowed without permission.

A common view about the practicalities of any future medical billing education suggested an applied learning approach would be more helpful than expecting medical practitioners to understand and interpret "legal wording." (GP8)

\section{Discussion}

\section{General knowledge of medical billing and the impact of third parties}

The qualitative data presented in this study suggest Australian medical practitioners are illequipped to manage their Medicare compliance obligations, have low levels of legal literacy and desire education, clarity and certainty around complex billing standards and rules. This is consistent with the results of prior survey findings in Australia ${ }^{4}$ as well as findings in other countries such as the U.S and Canada. ${ }^{14-16}$ This finding also aligns analysis of Australian medical billing policies which reported that a single Medicare service in Australia can be the subject of more than 30 different payment rates, multiple claiming methods and myriad rules. ${ }^{17}$

The data also suggest the current 'rules' of medical billing are confusing, and medical practitioners are struggling to understand and apply them in daily practice. Available evidence also suggests that recent Australian Government initiatives such as the MBS Review Taskforce $(\mathrm{MBSRT})^{18}$ may be exacerbating these problems by making it difficult for medical practitioners to keep pace with the Australian Governments' frenetic law making. ${ }^{2}$

All participants in this study commented on the potential negative impact of untrained third parties administering medical billing on their behalf. Participants described this standard 
medRxiv preprint doi: https://doi.org/10.1101/2020.05.26.20113324; this version posted December 1, 2020. The copyright holder for this preprint (which was not certified by peer review) is the author/funder, who has granted medRxiv a license to display the preprint in

All rights reserved. No reuse allowed without permission.

operating model as reducing the practical control and visibility they had over bills submitted to Medicare in their names, and was an area in which the law was out of step with the realities of modern medical practice management.

\section{Risks to State and Federal Government relations and public hospital funding}

Responses from participants suggested that while most medical practitioners have an awareness of the existence of the MBS (though many did not access or use it), they had no knowledge of the vast interconnected body of law that impacts their daily billing decisions, most notably the NHRA. ${ }^{13}$ The apparent lack of awareness of the NHRA by SMOs combined with demonstrably poor understanding of some of the most basic elements of correct billing such as the components of a valid referral, may have serious repercussions extending beyond individual practitioners. Whilst SMOs are required to comply with the complex provisions of the NHRA, they are not parties to it, so cannot personally breach an agreement they did not sign. The relevant signatories to the NHRA are the Federal and State Governments, the latter of whom may be exposed to investigation and substantial repayments to the Commonwealth caused by incorrect billing by the SMOs in their employ. This risk was recently identified by both the Victorian Auditor General ${ }^{19}$ and the Independent Commissioner Against Corruption in South Australia, ${ }^{20}$ and was illuminated in this study.

In a gatekeeper model health system such as Australia's Medicare, a valid referral from a GP is usually the starting point of a correct medical bill issued by a SMO, though this studies' data suggest SMOs may be unaware of the components of a valid referral. In addition, opaque legal drafting, inconsistent law making as between the NHRA and the Health Insurance Act 1973 (Cwth), (which has been the subject of earlier critical analysis) ${ }^{2}$ as well as inconsistent departmental interpretation of relevant legal provisions, may have extinguished any possibility 
medRxiv preprint doi: https://doi.org/10.1101/2020.05.26.20113324; this version posted December 1 , 2020. The copyright holder for this preprint (which was not certified by peer review) is the author/funder, who has granted medRxiv a license to display the preprint in perpetuity.

All rights reserved. No reuse allowed without permission.

of compliant billing in this important area and crippled the Federal Governments' ability to prosecute breaches when they occur. The mechanism of this process is shown in Figure 1.

Figure 1 Referral law inconsistencies between Medicare and NHRA and potential impact.

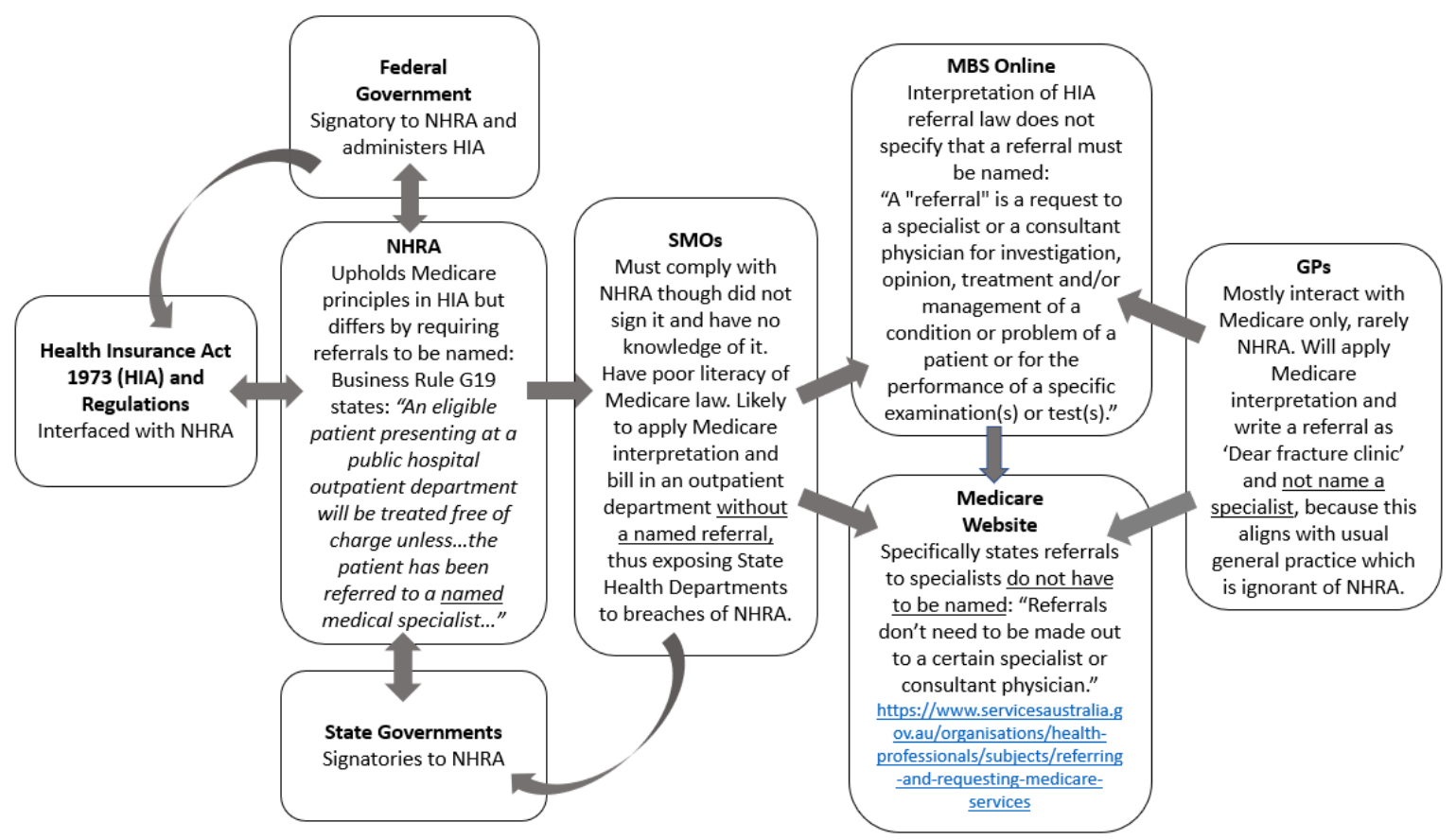

Another potential impact on public hospitals caused by disparate Federal and State agencies, is that well-intentioned, but siloed initiatives such as the MBSRT, may cause disruptions to legitimate revenue streams for State Governments when clinical code sets diverge. In a recent example, changes to the MBS colonoscopy items recommended by the MBSRT were introduced on 1 November 2019. These changes turned one MBS item number into seven, none of which matched the Australian Classification of Health Intervention Codes (ACHI). ${ }^{21} \mathrm{ACHI}$ codes have a number of purposes including to code private patient encounters in public hospitals and when the codes submitted by a medical practitioner using the MBS do not match the codes submitted by the hospital using ACHI, for the same episode of care, Private Health 
medRxiv preprint doi: https://doi.org/10.1101/2020.05.26.20113324; this version posted December 1, 2020. The copyright holder for this preprint (which was not certified by peer review) is the author/funder, who has granted medRxiv a license to display the preprint in

All rights reserved. No reuse allowed without permission.

Insurers may reject or delay payment, incorrectly assuming either the hospital or the medical practitioner has submitted a non-compliant bill.

ACHI codes are updated biennially and despite being derived from the MBS, often differ from the MBS for the very same service, because ACHI represent different concepts intended for different use cases and are the responsibility of the Independent Hospitals Pricing Authority (IHPA). ${ }^{21}$ IHPA is focussed on hospital morbidity and mortality, whereas members of the MBSRT were predominantly medical practitioners, who were understandably focussed on writing MBS service descriptions that meant something to them. In addition to impacting State Government revenue streams, this increasing divergence in our national clinical classifications and code sets may ultimately hamper full implementation of Australia's National Digital Health Strategy, which envisions standard semantic interoperability. ${ }^{22}$ To prevent this, it will be critical to ensure future code committees include individuals with the necessary skills to understand e-enabled health environments and work collaboratively aligning their codes with each other and with additional international codes already in use in Australia, such as SNOMED-CT and ICD-10AM.

\section{Medicare audit anxiety and cognitive dissonance}

Fear of Medicare audits was another issue highlighted by some participants, which appears to be contributing to overall feelings of anxiety and unease. This has the potential to impact patient care if medical practitioners make conservative treatment choices fuelled by fear of investigation, a potential sequela that has also been reported in the US. ${ }^{23}$ 
medRxiv preprint doi: https://doi.org/10.1101/2020.05.26.20113324; this version posted December 1, 2020. The copyright holder for this preprint (which was not certified by peer review) is the author/funder, who has granted medRxiv a license to display the preprint in

All rights reserved. No reuse allowed without permission.

When asked about the connection between their billing patterns and their responsibility for the national health budget, participants acknowledged their responsibility to bill correctly and distribute finite resources prudently. However, this sat at odds with earlier responses around a preference by all participants to remain disconnected from billing administration, which they felt was not what they had studied medicine to do. This represented a striking cognitive dissonance in which the space between thought and action was occupied by ignorance from inadequate education, and indifference to having oversight of their own health budget spend.

\section{Government maladministration}

This study found no evidence of the availability of reliable advice and support for billing questions, including from Medicare, with the main sources of information being medical colleagues and administrative staff who themselves have never been formally taught how to bill correctly, but whom medical practitioners feel they have no option but to trust. It was apparent that "the blind leading the blind" method by which medical billing information is disseminated may be perpetuating errors and myths. Further, the consistency in the experiences of the wide cross section of participants in this study supports a finding that extremely low levels of legal literacy in relation to medical billing is fact rather than hyperbole, and there may be a vortex of misinformation contributing to health system leakage.

Further, the data suggest that apparent maladministration by the Australian Government appears to have left medical practitioners with no place to go for legally accurate, reliable advice, meaning that despite due diligence, a medical practitioner may still fall foul of the law. In one case, a participant who had been billing correctly, was effectively led into incorrect billing by the Australian Government who appeared not to have understood its own rule. 
medRxiv preprint doi: https://doi.org/10.1101/2020.05.26.20113324; this version posted December 1, 2020. The copyright holder for this preprint (which was not certified by peer review) is the author/funder, who has granted medRxiv a license to display the preprint in All rights reserved. No perpetuity.

It would appear the Australian Government is either unable or unwilling to explain the very medical billing laws it promulgates, and as such, courts and other authorities must give due consideration to the veracity of any submission made by a medical practitioner under investigation for incorrect billing, relating to ignorance of relevant requirements or the potential impact of third parties on their billing. The participants of this study were clear that expecting medical practitioners to comply with complex billing laws without relevant skills or training was unrealistic. Moreover, it is suggested that denying medical practitioners access to clear, reliable advice and support prior to imposing sometimes very serious sanctions is indefensible and may be inconsistent with common law principles of natural justice. ${ }^{24}$

\section{Strengths and Limitations}

Strengths of the study include the wide cross section of participants, information gathering in a non-punitive setting, and the diverse practice settings of participants including primary care and tertiary hospital-based care. The study also provides valuable insights into barriers to medical billing compliance and offers possible solutions for reform.

However, the qualitative data is contextually limited by the Australian context of a predominantly fee-for-service payment structure so the findings may not be generalisable, though the results are broadly comparable and consistent with reports of the same phenomenon in both the U.S and Canada. ${ }^{14-16}$ Another limitation is the potential impact of selection bias caused by the recruitment methods wherein a participant with high ethical standards was likely to work in a practice with others having the same standards. However, any impact would have been limited to the three GP practices where more than one GP was interviewed and possibly in the public hospitals where multiple SMOs were interviewed. However, any impact is likely minimal as all participants worked and billed independently day 
medRxiv preprint doi: https://doi.org/10.1101/2020.05.26.20113324; this version posted December 1 , 2020. The copyright holder for this preprint (which was not certified by peer review) is the author/funder, who has granted medRxiv a license to display the preprint in

All rights reserved. No reuse allowed without permission.

to day, and most did not know each other. Seven of the participants were known to the principal researcher either directly or indirectly, however, any impact is also likely minimal because the line of questioning was consistent across all participants and results were cross checked multiple times by multiple researchers using the recognised methods already discussed.

\section{Conclusion}

Non-compliant medical billing under Australia's Medicare scheme is a nuanced phenomenon that may be far more complex than previously thought. Therefore, many of the current punitive, post payment audit initiatives of the government are unlikely to succeed, such as trying to nudge medical practitioners into compliance with non-existent or incomprehensible rules they have never been taught and do not understand.

Strategies to address the barriers and deficiencies identified by participants in this study will require a multi-pronged approach which may include the development of clear, legally binding medical billing rules, nationally consistent, accurate and accessible education, and structural reform, tightening and alignment of the underlying regulatory framework including aligning national code sets.

This is the first Australian study to examine the lived experiences of Australian medical practitioners interacting with Medicare and medical billing. Some of the experiences are shared with international experiences, and may therefore offer learnings for other countries implementing universal health coverage systems, in which payment integrity and control of system leakage are of critical importance.. The data suggest that the current system of ensuring compliance by medical practitioners in Australia is not fit for purpose. 
medRxiv preprint doi: https://doi.org/10.1101/2020.05.26.20113324; this version posted December 1, 2020. The copyright holder for this preprint (which was not certified by peer review) is the author/funder, who has granted medRxiv a license to display the preprint in All rights reserved. No reuse allowed without permission.

\section{Acknowledgments and funding}

The authors acknowledge the contribution of Heather Grain: Health Informatician, Clinical

Coder, Health Information Manager, Digital Health Expert, for her input into Australia's digital health environment and ACHI codes. The authors also wish to thank the medical practitioners who shared their experiences with medical billing and Medicare. The project received no funding. 
medRxiv preprint doi: https://doi.org/10.1101/2020.05.26.20113324; this version posted December 1 , 2020. The copyright holder for this preprint (which was not certified by peer review) is the author/funder, who has granted medRxiv a license to display the preprint in

All rights reserved. No reuse allowed without permission.

\section{References}

1. Gee, Jim; Button, Mark, The Financial Cost of Healthcare Fraud 2014: What Data from Around the World Shows. BDO Publishing, University of Portsmouth, 2014.

2. Margaret Faux, Jonathan Wardle and Jon Adams. Medicare Billing, Law and Practice: Complex, Incomprehensible and Beginning to Unravel: (2019) 27 JLM 66

3. Webber T, What is wrong with Medicare? MJA 196 (1) 16 January 2012

4. Faux $\mathrm{M}$, et al. Who teaches medical billing? A national cross-sectional survey of Australian medical education stakeholders: BMJ Open 2018; doi:10.1136/bmjopen-2017-020712 5. In 2019, the Australian Government introduced a new Shared Debt Recovery Scheme enabling the Department of Health to hold an organisation who employs or contracts a medical practitioner partially responsible for incorrect Medicare claims, as well as new data matching laws designed to detect breaches of rules such as prohibiting billing while a medical practitioner is overseas, which can now be easily determined by matching immigration and billing records. See, Australian Government, Department of Health, Health Professional Compliance, https://www1.health.gov.au/internet/main/publishing.nsf/Content/healthcompliance\#Changes (accessed 8 March 2020) and Parliament of Australia, Parliamentary Business, Health Legislation Amendment (Data-matching and Other Matters) Bill 2019 https://www.aph.gov.au/Parliamentary Business/Bills Legislation/Bills Search Results/Res ult?bld=r6441 (accessed 8 March 2020)

6. Michael Baigent and Ruth Baigent, Burnout in the medical profession: not a rite of passage, Med J Aust 2018; 208 (11): doi: 10.5694/mja17.00891

7. For example; Paz KB, Halverstam C, Rzepecki AK, McLellan BN, A National Survey of Medical Coding and Billing Training in United States Dermatology Residency Programs. Journal of Drugs in Dermatology: JDD, 01 Jun 2018, 17(6):678-682 PMID: 29879256, and Arora. A, Garg. A et al, National Survey of Pediatric Care Providers: Assessing Time and Impact of Coding and Documentation in Physician Practice, Clinical Pediatrics, 2018 https://doi.org/10.1177/0009922818774341 and Katherine A. Kelley, Heather E. Hoops et al Implementation of a medical coding curriculum for surgery residents, The American Journal of Surgery, Volume 217, Issue 5, May 2019, Pages 834-838

8. The MBS are unique billing codes used only in Australia. The MBS codes have no connection with the International Classification of Disease, Current Procedural Terminology, SNOMED-CT, LOINC or any other codes set or classification system.

9. P Liamputtong. D. E. 2005. Qualitative Research Methods, Melbourne, Oxford University Press.

10. Mays. P. A. 2006. Qualitative Research in Health Care, Blackwell Publishing Ltd.

11. Items 23 and 36 are commonly billed time-based GP attendance items. Item 23 is an attendance of less than 20 minutes and item 36 is from 20 to 40 minutes. Both have other requirements relating to complexity. They can be viewed at www.mbsonline.gov.au 12. Bulk billing is a common term in Australia, explaining a transaction for a medical service wherein the patient does not pay a gap to the medical practitioner. The formal legal process for bulk billing is described in Section 20A of the Health Insurance Act 1975 (Cwth), wherein an eligible person (a patient) assigns his/her right to a Medicare rebate to a medical practitioner and the medical practitioner is prohibited from charging a gap. It can be viewed at www.legislation.gov.au. In Australia, the term 'gap' refers to a patient out-of-pocket payment which in some countries may also be referred to as a co-payment. 
medRxiv preprint doi: https://doi.org/10.1101/2020.05.26.20113324; this version posted December 1 , 2020. The copyright holder for this preprint (which was not certified by peer review) is the author/funder, who has granted medRxiv a license to display the preprint in All rights reserved. No reuse allowed without permission.

13. National Health Funding Body, Public Hospital Funding, National Health Reform Agreement https://www.publichospitalfunding.gov.au/public-hospital-funding/aboutagreement (accessed 8 March 2020)

14. Andreae MC, D. K., Freed GL 2009. Inadequate training in billing and coding as perceived by recent pediatric graduates. Clin Pediatr (Phila). , 48, 939-944.

15. Jeff $L$. Waugh, Education in medical billing benefits both neurology trainees and academic departments, Neurology Nov 2014, 83 (20) 1856-1861;

DOI: 10.1212/WNL.0000000000000983.

16. Ryan E. Austin, MD, Herbert P. von Schroeder, MD, MSc, How accurate are we? A comparison of resident and staff physician billing knowledge and exposure to billing education during residency training. J Can Chir, Vol. 62, No 5, Octobre 2019.

17. Faux MS, Wardle JL, Adams J No payments, copayments and faux payments: are medical practitioners adequately equipped to manage Medicare claiming and compliance? Intern Med J 2015;45(2):221-7

18. In 2015 the Federal Government established a new body, called the MBS Review Taskforce (MBSRT). The stated purpose of the MBSRT was to align Medicare funded services with contemporary clinical evidence. The work of the MBSRT resulted in massive changes to MBS item numbers that were introduced in an ad hoc manner. For more information please access the Department of Health website at this link https://www1.health.gov.au/internet/main/publishing.nsf/Content/MBSReviewTaskforce 19. Victorian Auditor General's Office, Managing Private Medical Practice in Public Hospitals, Independent assurance report to parliament 2018-19:30 ISBN 9781925678550

20. Troubling Ambiguity: Governance in SA Health, A Report by the Honourable Bruce Lander QC, Independent Commissioner Against Corruption, published 29 November 2019. 21. The $\mathrm{ACHI}$ were originally derived from the MBS but have become increasingly disconnected from it, although usually retain a base item number, recorded on mapping tables. For more information including accessing the MBS/ACHI maps see the Independent Hospital Pricing Authority website https://www.ihpa.gov.au/

22. Australian Digital Health Agency, Australian Government, The National Digital Health Strategy. Details of semantic interoperability can be read at this link https://conversation.digitalhealth.gov.au/interoperability-and-data-quality

23. Greer Donley, The Broken Medicare Appeals System, Failed Regulatory Solutions and the Promise of Federal Litigation, Health Matrix - Volume 28 - Issue 1, 2018

24. Justice Alan Robertson, Natural Justice or Procedural Fairness, Judges and the Academy Speech 4 September 2015. Federal Court of Australia. Can be read at this link https://www.fedcourt.gov.au/digital-law-library/judges-speeches/justicerobertson/robertson-j-20150904 